\title{
EVALUASI DIKLAT PENINGKATAN KOMPETENSI PENILAIAN KINERJA GURU (PKG) DAN PENGEMBANGAN KEPROFESIONALAN BERKELANJUTAN (PKB)
}

\section{THE EVALUATION OF TRAINING FOR PROMOTING COMPETENCE OF TEACHER PERFORMACE ASSESMENT AND CONTINUOUS PROFESSIONAL DEVELOMPMENT}

\author{
Ai Nurjanah \\ Balai Pendidikan dan Pelatihan Keagamaan Bandung, Kementerian Agama RI \\ Email: anurjanah17@yahoo.co.id
}

Naskah Diterima: 16 Mei 2019; Direvisi: 24 Juli 2019; Disetujui: 15 November 2019

\begin{abstract}
The purpose of this study was to find out the effectiveness of substantive technical training implementation in improving the improvement of teacher performance and the continuous professional development that held in Bandung Religious Training Center on the year of 2017-2018 by using Kirkpatrick model. This research uses a mixed-methods with concurrent embedded types with a descriptive approach with 330 populations and 77 persons for the sample. The results for first level (reaction level) that the participants' reaction towards training organizer has shown an average satisfaction index of 82.12 (good). The Reaction of participants to widyaiswara was 82.8 (good) on average. At level 2 (learning level), The result of knowledge aspect's for $t$-test on pretest and posttest data correlated 0.34 with a significance level 0.003. It's was indicates that education and training have been succeeded to increase the training participants' knowledge. In the skill aspect, the average rating's product was 91.66 (very good). The average score of the attitude aspect was 88.6 (good). For the evaluation at level 3 (behaviour level), the average score of 61.96\% (47 graduated from training had shown that the training results were quite satisfying). From triangulation results of PostTraining Evaluation (EPD), the graduated from training gave positive manner statements for generally. Different from colleagues and superiors who gave negative statements. Evaluation at stage 4 (result level) demonstrated that the average percentage of $t$-score $63.64 \%$ or about 49 graduated had stated that they were able to obtain credit numbers according to the demand..
\end{abstract}

Keywords: Evaluation; Kirkpatrick model; PKG/PKB training

\begin{abstract}
Abstrak
Tujuan penelitian ini untuk mengetahui efektivitas penyelenggaraan diklat teknis substantif peningkatan kompetensi Peningkatan Kinerja Guru dan Pengembangan Keprofesionalan Berkelanjutan yang diselenggarakan di Balai Diklat Keagamaan Bandung tahun 2017-2018 menggunakan model Kirkpatrick. Penelitian ini menggunakan metode kombinasi (mixed methodes) tipe concurreent embedded dengan pendekatan deskriptif dengan jumlah populasi 330 serta sampel 77 orang. Hasil penelitian pada level 1 (reaction level), reaksi peserta terhadap penyelenggara diklat memiliki indeks kepuasan rata-rata sebesar 82,12 (baik). reaksi peserta terhadap widyaiswara ratarata sebesar 82,80 (baik). Pada level 2 (Learning level), evaluasi pada aspek pengetahuan hasil uji-t pada data pretest dan posttest memiliki korelasi 0,34 dengan taraf signifikansi 0,003, menunjukkan bahwa diklat berhasil meningkatkan pengetahuan peserta diklat. Pada aspek keterampilan rata-rata penilaian produk sebesar 91,66 (sangat baik). Pada aspek sikap skor rata-rata sebesar 88,6 pada (baik). Evaluasi pada level 3 (behavior level), rata-rata skor $t$ sebesar 61,96\% (47 orang alumni diklat menyatakan hasil diklat memiliki pengaruh yang baik). Dari hasil triangulasi Evaluasi Pasca Diklat, alumni diklat secara umum memberikan pernyataan positif, sedangkan rekan sejawat, dan atasan secara umum memberikan pernyataan negatif. Evaluasi pada tahap 4 - level hasil (result level), hasil evaluasi menunjukkan prosentase rata-rata skor-t sebesar $63,64 \%$ atau 49 orang alumni menyatakan dapat memperoleh angka kredit.
\end{abstract}

Kata Kunci: Diklat PKG dan PKB; Evaluasi; Model Kirkpatrick 


\section{PENDAHULUAN}

Diklat merupakan salah satu upaya peningkatan kualitas sumber daya manusia. Negara-negara maju sangat mementingkan kualitas sumber daya manusia, sehingga diklat pun menjadi program pokok yang diprioritaskan. Dalam banyak hal, diklat sudah dianggap sebagai human capital yang akan memberikan kontribusi bagi peningkatan kualitas organisasi. Pada sisi inilah, kemudian banyak ahli sumber daya manusia menganggap perlu adanya suatu evaluasi diklat sebagai bagian dari quality control dalam proses penjaminan mutu. Salah satu bentuk quality control pada kegiatan diklat adalah mengukur tingkat keberhasilan diklat (Sallis, 2010). Kontrol pada pelaksanaan diklat dimaksudkan untuk mengetahui ketercapaian program yang telah diselenggarakan. Pelaksanaan diklat pada dasarnya merupakan suatu proses pengalihan pengetahuan melalui pendidikan dan pelatihan yang memerlukan evaluasi untuk melihat apakah tujuan pendidikan dan pelatihan telah tercapai.

Undang-undang tentang Aparatur Sipil Negara pasal 3 huruf d menyatakan bahwa Aparatur Sipil Negara (ASN) sebagai profesi berlandaskan pada prinsip yang salah satunya adalah mempunyai kompetensi yang diperlukan sesuai dengan bidang tugas (Undang-undang, 2014a). Sesuai dengan pasal 70 Undang-undang tentang Aparatur Sipil Negara, sebagai upaya mengembangkan kompetensi bagi ASN tersebut, dapat dilakukan salah satunya melalui kegiatan pendidikan dan pelatihan (diklat) (Undang-undang, 2014b). Pelatihan dan pengembangan sumber daya manusia didefinisikan sebagai sebuah proses yang memanfaatkan berbagai metode untuk menyediakan keterampilan yang dibutuhkan, baik untuk pegawai baru maupun pegawai lama dalam melaksanakan pekerjaannya (Dessler and Angelica, 2015). Definisi tersebut selaras dengan definisi diklat Peraturan Pemerintah Tahun 2010 tentang Pendidikan dan Pelatihan Jabatan Pegawai Negeri Sipil, yaitu proses penyelenggaraan belajar mengajar dalam rangka meningkatkan kemampuan Pegawai Negeri Sipil. Adapun fungsi dari pelatihan dinyatakan oleh Noe, et al. dalam Ikramina and Gustomo (2014) adalah untuk mengembangkan pengetahuan dari pegawai tentang budaya perusahaan dan pesaingnya, untuk membantu pekerja yang mempunyai keterampilan dalam bekerja dengan menggunakan teknologi baru, untuk membantu pegawai dalam memahami bagaimana bekerja secara efisien dan efektif dalam sebuah tim yang bertujuan untuk produk dan pelayanan yang berkualitas, untuk menjamin budaya perusahaan yang menekankan pada inovasi, kreativitas, dan pengetahuan, untuk menjamin keselamatan dengan memberikan ide-ide tentang bagaimana pekerja dapat berkontribusi kepada perusahaan dalam jam kerja yang aman dan ketika para pegawai tersebut membutuhkan perubahan atau ketika suatu keterampilan baru dianggap wajib, serta untuk menyiapkan pegawai dalam menerima dan bekerja secara efektif antar sesama, khususnya dengan minoritas dan wanita.

Noe (2010) mengatakan bahwa untuk sementara waktu produktivitas kerja pun menjadi hilang ketika pegawai mengikuti pelatihan. Untuk meyakinkan bahwa program pelatihan yang diselenggarakan tidak sia-sia, maka perlu dilakukan evaluasi program pelatihan. Evaluasi mengenai dampak dan efektivitas dari pelatihan diperlukan agar kelebihan dan kekurangan dalam program tersebut dapat diidentifikasi sehingga perbaikan dapat ditindaklanjuti (Rouse, 2011 dalam Ramadhon, 2014). Hal tersebut sesuai dengan fungsi evaluasi yang dikemukakan (Badu, 2013) yaitu untuk memperoleh informasi yang akurat dan objektif pada sebuah program yang telah direncanakan dan diimplementasikan pada fase sebelumnya.

Sejalan dengan definisi dan fungsi evaluasi dari berbagai pendapat di atas, dalam (Undang-undang Tahun 2003) nomor 20 tentang Sistem Pendidikan Nasional Pasal 57 ayat (1), disebutkan bahwa evaluasi dilakukan dalam rangka pengendalian mutu pendidikan secara nasional sebagai bentuk akuntabilitas penyelenggara pendidikan kepada pihak-pihak yang berkepentingan, di antaranya terhadap peserta, lembaga dan program pendidikan.

Model-model evaluasi program dapat dikelompokkan, yaitu (1) Goal Oriented Evaluation; (2) Decision Oriented Evaluation; (3) Transactional Evaluation; (4) Goal Free Evaluation; (5) Adversary Evaluation; (6) Evaluasi Model Kirkpatrick (Issac and Michael, 1995). 
Diklat teknis substantif Peningkatan Kompetensi Penilaian Kinerja Guru (PKG)/ Pengembangan Keprofesionalan Berkelanjutan (PKB) yang diselenggarakan oleh Balai Diklat Keagamaan Bandung adalah salah satu diklat yang disenggarakan untuk meningkatkan pengetahuan guru-guru berkaitan dengan apa saja kebutuhan guru untuk memenuhi angka kreditnya. Masih ditemukan guru-guru di lingkungan Kementerian Agama di madrasahmadrasah, kesulitan dalam mengajukan angka kreditnya di antaranya karena pemahaman yang kurang tentang PKG dan PKB.

Berdasarkan hasil kegiatan diklat teknis substantif Peningkatan Kompetensi Penilaian Kinerja Guru (PKG) atau Pengembangan Keprofesionalan Berkelanjutan (PKB) dan laporan evaluasi pasca diklat ditemukan hasil diklat belum dapat menggambarkan sesuai dengan urgensi dari diklat itu. Hal yang tidak kalah pentingnya adalah informasi tentang dampak diklat terhadap peningkatan kinerja lulusan di tempat kerjanya masing-masing kemudian di evaluasi untuk mengkaji apakah diklat yang diikuti memberikan bekal yang bermanfaat. Diklat sebagai sebuah sistem harus menunjukkan model evaluasi program diklat yang sistematis di mana output dan outcome diklat belum menunjukkan kompetensi substansi masing-masing. Untuk itu penulis memandang perlu untuk menerapkan salah satu model evaluasi diklat yaitu model evaluasi Kirkpatrick untuk mengukur keberhasilan diklat Teknis Substantif Peningkatan kompetensi PKG dan PKB ini sampai kepada dampak dari hasil diklat yang telah diikuti oleh guru-guru kepada peningkatan pembelajaran di madrasah dan peningkatan karir guru itu sendiri. Sejauh ini evaluasi yang telah dilaksanakan pada diklat-diklat yang diselenggarakan di Balai Diklat Keagamaan Bandung masih belum memiliki alat ukur yang dapat menunjukkan kriteria keberhasilan dari diklat itu sendiri.

Dengan dasar-dasar tersebut di atas, penelitian diarahkan untuk mengangkat permasalahan pada diklat teknis substantif peningkatan kompetensi PKG dan PKB di Jawa Barat: 1) Bagaimana reaksi peserta diklat? 2) Bagaimana pembelajaran dan hasil belajar peserta diklat? 3) Bagaimana perilaku peserta diklat setelah di tempat kerjanya? 4) Apa yang telah dihasilkan peserta diklat?. Keempat masalah tersebut diharapkan dapat menunjukkan efektivitas diklat yang telah disenggarakan.

Penelitian ini dilaksanakan dengan tujuan: 1) untuk mengetahui bagaimana reaksi peserta diklat Teknis Subtantif Peningkatan Kompetensi PKG dan PKB yang diselenggarakan oleh Balai Diklat Keagamaan Bandung di Jawa Barat terhadap kualitas penyelenggaraan diklat pada Level 1 (reaction) model evaluasi Kirkpatrick) sesuai dengan standar kediklatan, 2) Untuk mengetahui bagaimana hasil belajar peserta diklat Teknis Substantif Peningkatan Kompetensi PKG dan PKB yang diselenggarakan oleh Balai Diklat Keagamaan Bandung di Jawa Barat berupa pengetahuan, keterampilan dan sikap yang diperoleh. (Level - 2 (learning) model evaluasi Kirkpatrick), 3)Untuk mengetahui bagaimana perilaku peserta pelatihan dalam mengimplementasikan keterampilan yang diperoleh dari diklat Teknis Substantif Peningkatan Kompetensi PKG dan PKB yang diselenggarakan oleh Balai Diklat Keagamaan Bandung di Jawa Barat pada Level-3 (behavior) model evaluasi Kirkpatrick, 4)untuk mengetahui bagaimana setelah diklat peserta memiliki hasil sebagai dampak dari implementasi keterampilan yang diperoleh setelah mengikuti pelatihan. Level-4 (result) model evaluasi Kirkpatrick.

Manfaat hasil penelitian diharapkan dapat memberikan gambaran hasil pengukuran diklat dengan menggunakan model Kirkpatrick empat level, level 1 reaksi peserta terhadap penyelenggaraan diklat, level 2 hasil pembelajaran peserta, level 3 kebiasaan peserta diklat setelah mengikuti diklat di tempat kerja masing-masing dan level 4 peserta diklat menunjukkan hasil sesuai dengan tujuan dari diklat teknis substantif peningkatan kompetensi PKG dan PKB yaitu dapat mencukupi angka kreditnya dan mengajukan DUPAK sehingga dapat naik pangkat.

\section{Kerangka Konsep}

\section{Pengertian Pendidikan dan Pelatihan}

Diklat mempunyai arti proses belajar mengajar dalam rangka meningkatkan 
kemampuan dalam melaksanakan tugas dan jabatan tertentu. Diklat yang diikuti merupakan jenis diklat yang dilaksanakan berdasarkan kebutuhan seseorang yang memegang jabatan atau pelaksana pekerjaan tiap jenis jabatan atau unit organisasi untuk meningkatkan pengetahuan, keterampilan dan sikap dalam melaksanakan tugas secara efektif dan efisien.

Pelatihan atau training merupakan bagian dari suatu proses pendidikan yang bertujuan untuk meningkatkan kemampuan atau keterampilan khusus karyawan atau institusi (Notoatmodjo, 2009). Pelatihan adalah suatu proses yang akan menghasilkan suatu perubahan perilaku bagi karyawan, Terdapat perbedaan istilah pendidikan dan pelatihan dalam suatu institusi. Pendidikan pada umumnya berkaitan dengan mempersiapkan calon tenaga yang diperlukan oleh suatu institusi atau organisasi, sedangkan pelatihan berkaitan dengan peningkatan kemampuan atau keterampilan karyawan yang sudah menduduki suatu pekerjaan atau tugas tertentu. Pelatihan umumnya menekankan pada kemampuan psikomotor, meskipun didasari pengetahuan dan sikap.

Pelatihan berorientasi pada pelaksanaan tugas serta keterampilan khusus pada sasaran yang umumnya lebih pendek dari pada pendidikan. Pada akhir suatu proses pelatihan biasanya peserta hanya memperoleh sertifikat, sedangkan pada akhir pendidikan peserta pada umumnya memperoleh ijazah atau gelar. Pelatihan mengacu pada upaya yang direncanakan oleh perusahaan untuk memfasilitasi karyawan mempelajari kompetensi yang berkaitan dengan pekerjaan (Noe, 2010). Kompetensi ini mencakup pengetahuan, keterampilan, atau perilaku yang sangat penting untuk keberhasilan pekerjaan.

\section{Evaluasi Diklat}

Evaluasi penyelenggaraan diklat
dilakukan meningkatkan
penyelenggaraan diklat berikutnya. Evaluasi ini
dilakukan pada akhir diklat berkaitan dengan
kinerja panitia penyelenggara, manfaat diklat
secara keseluruhan, akomodasi, konsumsi,
pelayanan dan sebagainya. Evaluasi program
bertujuan untuk mengetahui pencapaian tujuan
program yang telah dilaksanakan (Arthur, 2018

p.37). Selanjutnya, hasil evaluasi program digunakan sebagai dasar untuk melakukan kegiatan tindak lanjut atau untuk pengambilan keputusan selanjutnya

Pelaksanaan evaluasi penyelenggaraan diklat pada kementerian Agama mengikuti standar evaluasi berdasarkan keputusan Kepala Badan Penelitian dan Pengembangan serta Pendidikan dan Pelatihan Kementerian Agama Nomor BD/BD/60/2012 tentang Petunjuk Teknis Penyelenggaraan Diklat Tenaga Teknis Pendidikan dan Keagamaan. Ruang lingkup evaluasi penyelenggaraan diklat teknis meliputi yaitu 1) evaluasi terhadap peserta, 2) evaluasi terhadap penyelenggara, 3) evaluasi terhadap widyaiswara, 4) evaluasi terhadap program diklat teknis.

\section{Evaluasi Model Kirkpatrick}

Model evaluasi pelatihan yang dikembangkan pertama kali oleh Donald. L. Kirkpatrick dengan menggunakan empat level dalam mengategorikan hasil-hasil pelatihan. Kirkpatrick and James (2008), mengemukakan tiga alasan spesifik dalam melakukan evaluasi program pelatihan, yaitu: untuk menjustifikasi keberadaan anggaran pelatihan dengan memperlihatkan bagaimana program pelatihan tersebut berkontribusi pada tujuan dan sasaran organisasi; untuk menentukan apakah suatu program pelatihan dilanjutkan atau tidak; serta untuk memperoleh informasi mengenai bagaimana cara meningkatkan program pelatihan dimasa datang. Metode evaluasi empat level merepresentasikan sebuah sekuen dari setiap tahapan untuk mengevaluasi program pelatihan menurut Meghe, B., Bhise, V., P., \& Muley, A. (2013) dalam Ulum (2015). Maksud dari sekuen adalah setiap level harus dilakukan secara bertahap. Hal tersebut disebabkan setiap level dalam model empat level adalah penting dan setiap level memberi dampak pada level berikutnya. Empat level tersebut adalah: Level 1-Reaction (Reaksi), Level 2-Learning (Pembelajaran), Level 3Behavior (Perilaku), dan Level 4-Results (Hasil/Dampak), langkah-langkahnya dapat dilihat dalam Tabel 1. 
Tabel 1. Langkah-langkah Evaluasi Model Kirkpatrick

\begin{tabular}{ll}
\hline $\begin{array}{l}\text { Level 1 } \\
\text { (reaction/reaksi) }\end{array}$ & $\begin{array}{l}\text { Pada level ini, peneliti melaksanakan evaluasi terhadap tanggapan } \\
\text { kepuasan peserta terhadap pelaksanaan, informasi dapat diperoleh dari } \\
\text { lembar evaluasi terhadap widyaiswara/narasumber dan evaluasi peserta } \\
\text { terhadap penyelenggara diklat. }\end{array}$ \\
\hline Level 2 & Untuk memperoleh informasi pada level ini, peneliti mengumpulkan \\
(learning/pembelajaran) & data dari hasil pengukuran terhadap peserta tentang kompetensi \\
& pengetahuan, keterampilan dan sikap. Untuk pengukurtan kompetensi \\
& pengetahuan dengan menggunakan pretest dan posttest. Pada aspek \\
& keterampilan dan sikap dilakukan menggunakan lembar observasi \\
& selama pelaksanaan pembelajaran berlangsung. \\
\hline Level 3 & \begin{tabular}{l} 
Pada level 3, pengukuran perilaku peserta diklat dilaksanakan setelah \\
(behavior/perilaku) \\
selesai diklat (pasca diklat) menggunakan kuesioner dan pedoman \\
wawancara. Responden pada level behavior ini terdiri dari alumni \\
diklat, atasan langsung, dan teman sejawat. \\
\hline Level 4 \\
Pada level 4. Pengukuran dilaksanakan dengan menyebarkan kuesioner \\
bersamaan waktunya dengan pengambilan data pada level 3. Pada level \\
ini, hasil yang diharapkan adalah peserta diklat memperoleh angka \\
kredit untuk proses kenaikan pangkat dan mendapatkan SK atau terjadi \\
peningkatan karir.
\end{tabular} \\
\hline
\end{tabular}

\section{Penilaian Kinerja Guru dan Pengembangan Keprofesionalan Berkelanjutan}

Dalam Permen PAN-RB nomor 16 tahun 2009 tentang jabatan Fungsional Guru dan Angka Kreditnya. Dalam Bab I Pasal 1 ayat 8 disebutkan: "Penilaian kinerja Guru adalah penilaian dari tiap butir kegiatan tugas utama Guru dalam rangka pembinaan karier kepangkatan dan jabatannya". Selain itu, juga menyatakan bahwa penilaian kinerja guru adalah penilaian yang dilakukan terhadap setiap butir kegiatan tugas utama guru dalam rangka pembinaan karir, kepangkatan, dan jabatannya. Pelaksanaan tugas utama guru tidak dapat dipisahkan dari kemampuan seorang guru dalam penguasaan dan penerapan kompetensinya.

Penilaian kinerja guru dilakukan sekali dalam setahun, tetapi prosesnya dilakukan sepanjang tahun terutama dalam memantau unjuk kerja guru dalam mengimplementasikan kompetensi kepribadian dan kompetensi sosial. Kegiatan penilaian kinerja guru diawali dengan kegiatan evaluasi diri yang dilaksanakan pada awal semester. Rentang waktu antara pelaksanaan kegiatan evaluasi diri dan kegiatan penilaian kinerja guru adalah 2 semester.

Berdasarkan Peraturan Menteri Pendidikan Nasional nomor 16 tahun 2007 tentang Standar Kualifikasi Akademik dan Kompetensi Guru terdapat 4 (empat) kompetensi yang harus dimiliki guru yaitu kompetensi pedagogik, kepribadian, sosial, dan profesional dengan 14 (empat belas) subkompetensi sebagaimana yang telah dirumuskan oleh Badan Standar Nasional Pendidikan (BSNP). Sedangkan dalam Peraturan Menteri Pendidikan Nasional Nomor 27 Tahun 2008 tentang Standar Kualifikasi Akademik dan Kompetensi Konselor menjelaskan bahwa seorang guru BK/Konselor juga harus memiliki 4 (empat) kompetensi (pedagogik, keperibadian, sosial, dan profesional) dengan 17 sub-kompetensi.

Pengembangan keprofesian berkelanjutan mencakup kegiatan perencanaan, pelaksanaan, evaluasi, dan refleksi yang didesain untuk meningkatkan karakteristik, pengetahuan, pemahaman, dan keterampilan sebagaimana digambarkan pada diagram berikut ini (diadopsi dari Center for Continuous Professional Development (CPD). University of Cincinnati Academic Health Center. (http://webcentral.uc.edu/-cpd_online2).

Unsur-unsur Pengembangan Keprofesian Berkelanjutan (PKB) Guru dapat diamati pada Tabel 2. 
Tabel 2. Unsur-unsur Pengembangan Keprofesian Berkelanjutan (PKB)

\begin{tabular}{|c|c|c|}
\hline No. & Unsur & Sub Unsur \\
\hline 1. & Pendidikan & $\begin{array}{l}\text { A. Pendidikan sekolah dan mendapat ijazah/gelar (3) } \\
\text { B. Diklat prajabatan dan memperoleh STTPP atau sertifikat (1) }\end{array}$ \\
\hline 2. & $\begin{array}{l}\text { Pembelajaran/Bim } \\
\text { bingan \& Tugas } \\
\text { Tertentu }\end{array}$ & $\begin{array}{l}\text { A. Melaksanakan proses pembelajaran (1) } \\
\text { B. Melaksanakan proses pembimbingan (1) } \\
\text { C. Melaksanakan tugas lain yang relevan dengan fungsi sekolah (13) }\end{array}$ \\
\hline 3. & $\begin{array}{l}\text { Pengembangan } \\
\text { Keprofesian } \\
\text { Berkelanjutan }\end{array}$ & $\begin{array}{l}\text { A. Melaksanakan pengembangan diri (diklat \& kegiatan kolektif untuk } \\
\text { peningkatan kompetensi) (10) } \\
\text { B. Melaksanakan publikasi ilmiah (23) } \\
\text { C. Melaksanakan karya inovatif (12) }\end{array}$ \\
\hline & $\begin{array}{l}\text { Penunjang tugas } \\
\text { guru }\end{array}$ & $\begin{array}{l}\text { A. Perolehan gelar/ijazah yang tidak sesuai dengan bidang yang } \\
\text { diampu (3) } \\
\text { B. Melaksanakan kegiatan yang mendukung tugas guru (9) } \\
\text { C. Perolehan penghargaan/tanda jasa (4) }\end{array}$ \\
\hline
\end{tabular}

\section{METODE PENELITIAN}

Penelitian ini adalah penelitian evaluasi yang bertujuan untuk mengetahui efektivitas penyelenggaraan diklat teknis substantif peningkatan kompetensi PKG dan PKB yang diselenggarakan di Balai Diklat Keagamaan Bandung baik terhadap reaksi peserta terhadap kualitas penyelenggaraan pelatihan, keterampilan peserta setelah mengikuti pelatihan, implementasi keterampilannya serta dampak/hasilnya. Penelitian ini menggunakan metode penelitian kombinasi (maxed methods) desain concurrent embedded (campuran tidak berimbang) dengan pendekatan deskriptif.

\section{Creswell (2009) dalam Sugiyono} (2011), menyatakan bahwa metode penelitian kombinasi akan berguna bila metode kuantitatif atau kualitatif secara sendiri-sendiri tidak cukup akurat digunakan untuk memahami permasalahan penelitian, atau dengan menggunakan metode kualitatif dan kuantitatif secara kombinasi akan dapat memperoleh pemahaman yang paling baik (bila dibandingkan dengan satu metode). Desain concurrent embedded (campuran tidak berimbang) yaitu metode penelitian yang menggabungkan antara metode penelitian kualitatif dengan kuantitaif dengan cara mencampur kedua metode tersebut secara tidak seimbang. Metode tersebut digunakan secara bersama-sama, dalam waktu yang sama, tetapi independen untuk menjawab rumusan masalah yang sejenis (Sugiyono, 2011).

Indikator dari variabel evaluasi diklat teknis substantif peningkatan kompetensi PKG dan PKB guru madrasah menggunakan model Kirkpatrick sebagai berikut:

1. Mengukur reaksi peserta (reaction level). Alat ukur yang digunakan yaitu kuesioner berupa persepsi kepuasan peserta terhadap penyelenggaraan diklat teknis substantif peningkatan kompetensi PKG dan PKB bagi guru madrasah, terdiri dari panitia dan widyaiswara atau narasumber pada diklat di wilayah kerja.

2. Mengukur (learning level), hasil pembelajaran baik aspek pengetahuan, keterampilan dan sikap. Aspek pengetahuan dilaksanakan dengan menggunakan soal pretest dan post-test, sedangkan kompetensi keterampilan dan sikap dilaksanakan dengan menggunakan lembar obervasi berupa hasil kemampuan performance/unjuk kerja dalam menyelesaikan tugas-tugas baik secara individu ataupun kelompok, dan pada aspek sikap menggunakan lembar observasi terhadap perilaku peserta diklat selama melaksanakan pembelajaran.

3. Mengukur behavior level atau perilaku peserta diklat, atasan langsung peserta diklat dan teman sejawat serta pengguna (user). Pengukuran dilakukan dengan menyebarkan kuesioner, pada tahun 2019 (minimal tiga (3) bulan setelah diklat dilaksanakan) atau evaluasi pasca diklat.

4. Mengukur (result level) atau hasil sebagai dampak dari penerapan keterampilan yang diperoleh peserta dari hasil diklatnya. Pengukuran dilakukan dengan menyebarkan kuesioner bersamaan dengan pengukuran level 3 - reaksi. 
Jumlah populasi sebanyak 330 terdiri dari peserta diklat teknis substantif peningkatan kompetensi PKG dan PKB bagi guru madrasah pada diklat di wilayah kerja Balai Diklat Keagamaan Bandung tahun 2017 dan 2018 dari
11 kota/kabupaten di Jawa Barat. Metode pengambilan sampel dengan teknik purposive sampling. Untuk menentukan jumlah sampel digunakan kriteria sebagai berikut:

Tabel 3. Hasil purposive sampling

\begin{tabular}{|c|c|c|}
\hline No. & Kriteria sampel & $\begin{array}{c}\text { Jumlah } \\
\text { Kabupaten/Kota }\end{array}$ \\
\hline & $\begin{array}{l}\text { Jumlah kabupaten/kota tempat DDWK teknis substantif peningkatan } \\
\text { kompetensi PKG/PKB }\end{array}$ & $\begin{array}{lr}11 \quad(30 & \text { orang } \\
\text { peserta } & \text { per } \\
\text { angkatan }) & \end{array}$ \\
\hline 1. & $\begin{array}{l}\text { Tersedianya data lengkap dari laporan hasil diklat teknis substantif } \\
\text { peningkatan kompetensi PKG/PKB mulai dari data nilai peserta } \\
\text { terhadap penyelenggara, penilaian peserta terhadap } \\
\text { widyaiswara/narasumber, hasil nilai peserta. }\end{array}$ & 3 \\
\hline & $\begin{array}{l}\text { Lokasi Kanmenag Kementerian Agama tempat diklat mudah } \\
\text { terjangkau oleh alumni diklat maupun oleh peneliti ketika mengisi } \\
\text { instrumen level } 3 \text { (tiga) dan } 4 \text { (empat) putaran ke dua, untuk } \\
\text { mengefektifkan waktu dan biaya. }\end{array}$ & 8 \\
\hline 3. & $\begin{array}{l}\text { Pengambilan sampel berdasarkan keterwakilan dari waktu pelaksanaan } \\
\text { ataupun wilayah. }\end{array}$ & 4 \\
\hline & $\begin{array}{l}\text { Keterbatasan waktu dan biaya untuk penelitian juga menjadi } \\
\text { pertimbangan peneliti untuk dapat menyebarkan instrumen. }\end{array}$ & 2 \\
\hline & Jumlah & 3 \\
\hline
\end{tabular}

Sampel dalam penelitian ini berjumlah 77 responden, dengan lokus di tiga kabupaten yaitu kabupaten Tasikmalaya, kabupaten Subang dan kabupaten Purwakarta.

Metode pengumpulan data dilakukan dengan 5 (lima) cara yaitu: 1) observasi, 2) wawancara, 3) dokumentasi, 4) kuesioner dan 5) triangulasi data. Sedangkan instrumen yang digunakan pada penelitian ini adalah angket dan tes obyektif. Analisis data kualitatif dilakukan apabila data empiris yang diperoleh adalah data kualitatif berupa kumpulan berwujud kata-kata bukan rangkaian angka serta tidak dapat disusun dalam kategori/struktur klasifikasi (Silalahi, 2012). Menurut Miles dan Huberman dalam Silalahi (2012) menyebutkan bahwa kegiatan analisis terdiri dari tiga alur, yaitu 1) reduksi data, 2) penyajian data, dan 3) penarikan kesimpulan/verifikasi.

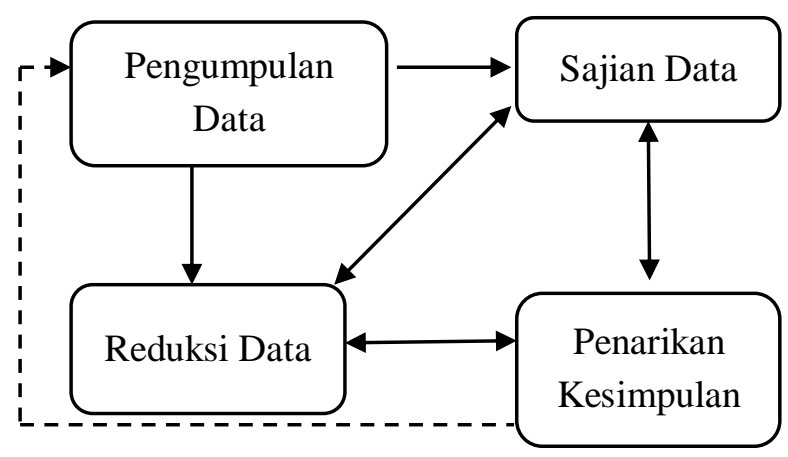

Gambar 1. Teknik Analisis Data Kualitatif (Sugiyono, 2008)

Pada tahap reduksi data, peneliti mengumpulkan informasi pada level 1. Skor yang diperoleh diberi bobot dengan rentang skor 50-100. Hasil penskoran ditabulasi dengan bantuan program excell. Pada level 2, data diperoleh dari hasil pretest dan post-test peserta, selanjutnya diuji dengan cara paired sample $\mathrm{t}$ test. Pada cara ini uji-t dilakukan terhadap dua sampel yang berpasangan. Uji-t dilakukan 
dengan menggunakan bantuan SPSS 19. Untuk uji-t nya dipergunakan hipotesis:

$\mathrm{H}_{0}$ : Kedua sampel rata-rata adalah sama (rata-rata pretest sama dengan posttest)

$\mathrm{H}_{1}$ : Kedua sampel rata-rata adalah berbeda (rata-rata pretest berbeda dengan posttest)

Sampel akan diuji normalitas dan homogenitasnya, selanjutnya diuji-t dan disimpulkan:

1. Jika statistik hitung > statistik tabel, maka $\mathrm{H}_{0}$ ditolak

2. Jika statistik hitung < statistik tabel, maka $\mathrm{H}_{1}$ diterima

Pada level 3 dan 4, data yang sudah dikumpulkan diolah dari data mentah diberikan skor 1 untuk jawaban dari pernyataan yang sesuai atau positif dan skor 0 untuk pernyataan yang tidak sesuai atau negatif. Selanjutnya dihitung dengan menggunakan rumus t-skor, sebagai berikut:

$$
\text { skor }-t=50-10\left[\frac{x-\bar{x}}{s}\right],
$$

Untuk menentukan sikap positif (favorable) dan sikap negatif (unfavorable) responden, skor-t yang sudah diperoleh kemudian dicari nilai rata-rata, dan nilai tengah, kemudian diklasifikasi sebagai berikut:

a. Sikap Positif (favorable) jika titik tengah skor-t > rata-rata kelompok skor-t b. Sikap negatif (unfavorable) jika titik tengah skor-t $\leq 50$ rata-rata kelompok skor-t.

Untuk triangulasi data diperoleh dari data Evaluasi Pasca Diklat.

\section{HASIL DAN PEMBAHASAN}

Evaluasi diklat teknis substantif peningkatan kompetensi PKG dan PKB dilaksanakan dengan menggunakan model Kirkpatrick dengan empat level. Pada level 1 (reaction level), level 2 (learning level), level 3 (behavior level) tahap 1 dan level 4 (result level) tahap 1 menggunakan instrumen yang telah divalidasi dan sudah digunakan untuk seluruh diklat yang diselenggarakan oleh Balai Diklat Keagamaan Bandung sehingga peneliti hanya melalukan uji coba instrumen untuk mengukur pada level 3 (behavior level) dan level 4 (result level). Hasil evaluasi dengan menggunakan model Kirkpatrick diperoleh sebagai berikut:

\section{Hasil evaluasi tahap 1-level reaksi (reaction level)}

Hasil evaluasi peserta terhadap penyelenggaraan diklat teknis substantif peningkatan kompetensi PKG dan PKB di Jawa Barat tahun 2017 dan tahun 2018, dapat dilihat pada Gambar 1 tentang data sebaran hasil evaluasi peserta terhadap penyelenggara.

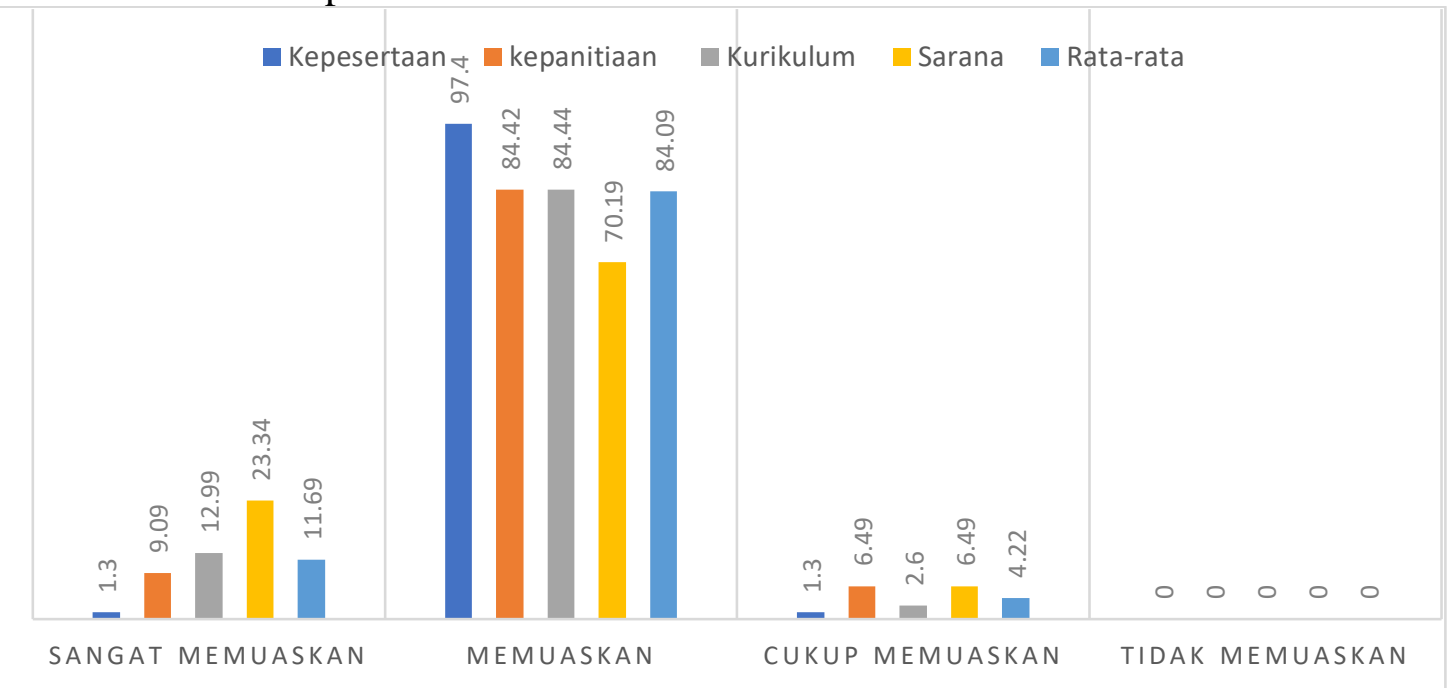

Gambar 2. Data Sebaran Hasil Evaluasi Peserta Terhadap Penyelenggara

Dari gambar di atas, menunjukkan skor rata-rata dari hasil evaluasi peserta terhadap penyelenggaraan diklat secara umum pada setiap aspek memuaskan. Sedangkan skor ratarata hasil kepuasan peserta evaluasi terhadap penyelenggaraan diklat per aspek yang dikonversi menjadi kategori reaksi terhadap penyelenggaraan diklat, maka dapat digambarkan dalam Tabel 4. 
Secara umum hasil evaluasi peserta terhadap penyelenggara pada instrumen evaluasi terhadap widyaiswara menunjukkan rata-rata kepuasan, yaitu aspek 1) pengetahuan menunjukkan kategori baik dalam penguasaan materi, sistematika penyajian dan ketercapaian tujuan pada semua mata diklat disajikan pada diklat PKG dan PKB; 2) keterampilan menunjukkan kategori baik dalam kemampuan menyajikan, penggunaan metode dan alat bantu pembelajaran, mengelola kelas, cara menjawab pertanyaan peserta, dan pemberian motivasi rata-rata untuk seluruh mata diklat pada diklat PKG dan PKB; 3) sikap menunjukkan baik dalam etika, sikap terhadap peserta, penggunaan bahasa, disiplin waktu, dan kerja sama dalam tim untuk seluruh mata diklat pada diklat PKG dan PKB; 4) secara keseluruhan aspek widyaiswara direkomendasi-kan untuk tetap melakukan DIKJARTIH dan disarankan untuk lebih meningkatkan lagi kompetensi profesi.

Tabel 4. Hasil rata-rata hitung reaksi evaluasi peserta terhadap penyelenggaraan diklat

\begin{tabular}{|c|c|c|c|}
\hline No. Aspek penyelenggaraan diklat & Skor rata-rata & Kategori & Total nilai rata-rata \\
\hline $\begin{array}{l}\text { 1. Kepesertaan } \\
\text { a. penetapan peserta } \\
\text { b. pemanggilan peserta }\end{array}$ & 82,5 & Baik & \multirow{4}{*}{82,12} \\
\hline $\begin{array}{l}\text { 2. Kepanitiaan } \\
\text { a. pelayanan terhadap peserta } \\
\text { b. kedisiplinan panitia }\end{array}$ & 81,26 & Baik & \\
\hline $\begin{array}{l}\text { 3. Kurikulum Diklat } \\
\text { a. materi diklat } \\
\text { b. manfaat diklat }\end{array}$ & 82,04 & Baik & \\
\hline $\begin{array}{l}\text { 4. Sarana Diklat } \\
\text { a. ruangan kelas } \\
\text { b. media pembelajaran }\end{array}$ & 82,69 & Baik & \\
\hline
\end{tabular}

\section{Hasil evaluasi tahap 2-level pembelajaran (learning level)}

Evaluasi pada tahap 2 (level learning) untuk mengetahui pencapaian kompetensi peserta diklat, pengukuran terdiri pada 3 aspek, yaitu pengetahuan, keterampilan dan sikap. Teknik penilaian menggunakan pretest dan posttest pelatihan, pengamatan, pemantauan dan penilaian pada saat proses pembelajaran menggunakan lembar observasi. Penilaian ini dilaksanakan oleh widyaiswara dan panitia penyelenggara diklat baik pada saat proses pembelajaran ataupun setelah pembelajaran dan pelatihan.

\section{Evaluasi pada aspek pengetahuan}

Untuk tahap 2-level pembelajaran pada aspek pengetahuan, peneliti mengumpulkan skor hasil pretest dan posttest peserta. Data yang terkumpul diuji dengan cara paired sample t test. Pada cara ini uji-t dilakukan terhadap dua sampel yang berpasangan dengan menggunakan SPSS 19.

Tabel 5. Perhitungan mean hasil pretest dan posttest

\begin{tabular}{crrrrr}
\hline \multicolumn{5}{c}{ Paired samples statistics } \\
\hline \multicolumn{7}{c}{ Mean } & N & Std. deviation & Std. error mean \\
\hline Pair & Pretes & 54,0519 & 77 & 7,89219 &, 89940 \\
1 & Postes & 66,8182 & 77 & 7,83334 &, 89269
\end{tabular}

Dari tabel tersebut tampak ada perbedaan mean pretest dan posttest. Mean pretes 54,05 dan standar deviasinya 7,89 sedangkan mean posttest 66,81 dan standar deviasinya 7,83 . Tabel 6 , memuat korelasi antara nilai pretest dan posttest. 
Tabel 6. Korelasi antara nilai pretest dan nilai posttest

\begin{tabular}{lcccrr}
\hline \multicolumn{5}{c}{ Paired samples correlations } \\
\hline & $\mathrm{N}$ & Correlation & Sig. & \\
\hline Pair 1 & Pretes \& Postes & 77 & &, 335 & \\
\hline
\end{tabular}

Pada tabel tersebut antara pretest dan posttest memiliki korelasi 0,34 dengan taraf signifikansi 0,003. Dapat disimpulkan bahwa nilai pretest peserta diklat $\mathrm{PKG} / \mathrm{PKB}$ memiliki korelasi yang cukup dengan nilai posttest peserta diklat PKG/PKB atau dengan kata lain diklat PKG/PKB secara nyata dan cukup memberikan korelasi terhadap hasil belajar peserta diklat. Artinya peserta diklat mengalami peningkatan pengetahuan dalam program pelatihan tersebut. Hasil perhitungan sampel berpasangannya disajikan pada Tabel 7 .

Tabel 7. Hasil Perhitungan Sampel Berpasangan

Paired Samples Test

\begin{tabular}{|c|c|c|c|c|c|c|c|c|}
\hline & \multicolumn{5}{|c|}{ Paired Differences } & \multirow[b]{3}{*}{ t } & \multirow[b]{3}{*}{$\mathrm{df}$} & \multirow[b]{3}{*}{ Sig. (2-tailed) } \\
\hline & \multirow[b]{2}{*}{ Mean } & \multirow[b]{2}{*}{ Std. Deviation } & \multirow{2}{*}{$\begin{array}{l}\text { Std. Error } \\
\text { Mean }\end{array}$} & \multicolumn{2}{|c|}{$\begin{array}{l}95 \% \text { Confidence Interval of the } \\
\text { Difference }\end{array}$} & & & \\
\hline & & & & Lower & Upper & & & \\
\hline Pair 1 Pretes-Postes & $-12,76623$ & 9,06685 & 1,03326 & $-14,82416$ & $-10,70831$ & $-12,355$ & 76 & 000 \\
\hline
\end{tabular}

Untuk uji t nya dipergunakan hipotesis:

$\mathrm{H}_{0}$ : kedua sampel rata-rata adalah sama (ratarata pretest sama dengan postest)

$\mathrm{H}_{1}$ : sampel kedua rata-rata adalah berbeda (rata-rata pretest berbeda dengan posttest)

Pengujian hipotesis dengan taraf signifikansi $(\mathrm{sig})=0,05$ dan derajat kebebasan (df $\mathrm{n}-1$ ) atau dapat ditulis $(5 \% ; 76)$ dilakukan dengan kriteria: 1) Berdasakan nilai $\mathrm{T}_{\text {hitung }}$ :

Tolak $\mathrm{H}_{0}$ jika $\mathrm{T}_{\text {hitung }}>\mathrm{T}_{\text {tabel }}(5 \%, \mathrm{n}-1)$ dan terima $\mathrm{H}_{1}$ jika $\mathrm{T}_{\text {hitung }}<\mathrm{T}_{\text {tabel }}(5 \%, \mathrm{n}-1)$. Dari tabel 3 terlihat bahwa nilai $\mathrm{T}_{\text {hitung }}=$ 12,355. Dari tabel nilai presentil untuk distribusi $\mathrm{t}$, diperoleh nilai $\mathrm{T}_{\text {tabel }}(5 \% ; 76)=$ 1,67. Kesimpulan pengujian berdasarkan nilai $\mathrm{T}_{\text {hitung }}$ adalah $\mathrm{T}_{\text {hitung }}-12,355<\mathrm{T}_{\text {tabel }}$ (5\%, n-1) 1,67 sehingga Tolak $\mathrm{H}_{0}$ dan terima $\mathrm{H}_{1}$. Hal ini dapat diartikan bahwa rata-rata pretest dan rata-rata posttest memang berbeda yang diakibatkan oleh adanya pembelajaran diklat $\mathrm{PKG} / \mathrm{PKB}$ oleh widyaiswara.

2) Berdasarkan nilai sig :

Jika nilai sig $>0.05$, maka $\mathrm{H}_{0}$ dan terima $\mathrm{H}_{1}$ jika nilai sig $<0.05$ dari tabel 3 diperoleh bahwa nilai signifikansi $=0.00$. Jelas sig $0.00<0.05$, oleh karena terima $\mathrm{H}_{1}$ dan tolak $\mathrm{H}_{0}$.

\section{Evaluasi pada aspek keterampilan}

Hasil pengumpulan skor perolehan dibagi dengan skor maksimal pada skala 0-100 diperoleh 77 skor rata-rata responden menjadi skor rata-rata kelas. Secara umum hasil rata-rata hitung sebesar 81 berada pada kategori baik. Secara terperinci dapat digambarkan pada Gambar 3.

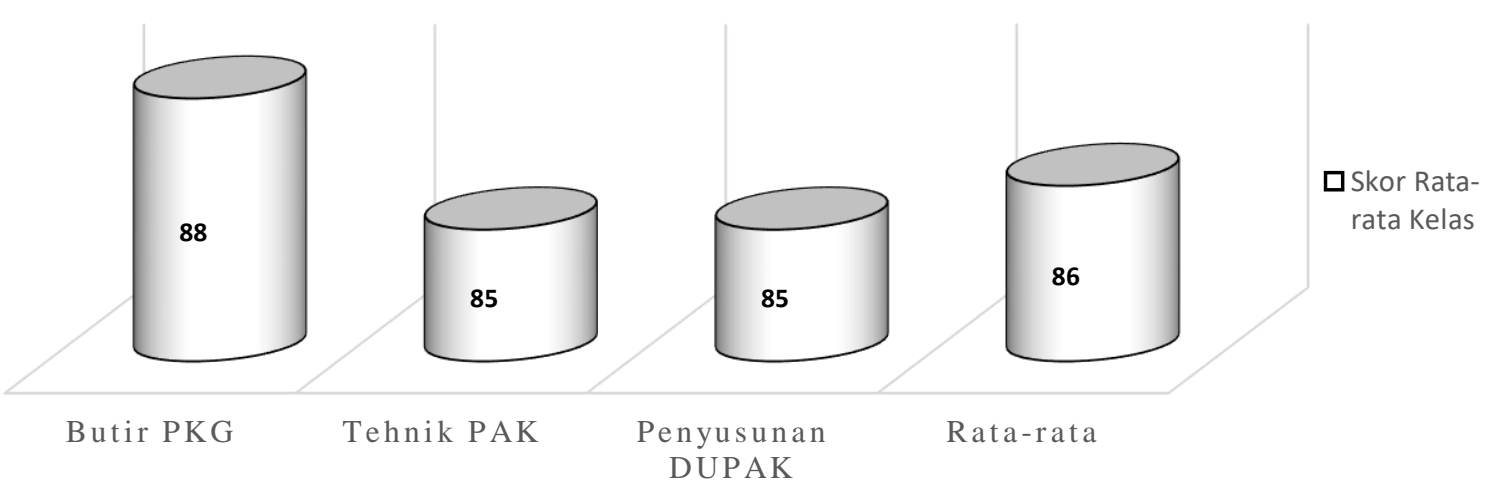

Gambar 3. Grafik skor rata-rata hasil produk setiap materi 
Berdasarkan Gambar 3 di atas skor ratarata kelas untuk produk instrumen butir penilaian kinerja guru sebesar 88 menunjukkan rata-rata pada kategori sangat baik, teknik penilaian angka kredit sebesar 85 menunjukkan rata-rata pada kategori sangat baik, dan penyusunan DUPAK guru sebesar 85 menunjukkan rata-rata pada kategori sangat baik. Jadi, skor rata-rata penilaian produk sebesar 86 menunjukkan rata-rata pada kategori baik.

\section{Evaluasi pada aspek sikap}

Hasil pengumpulan skor perolehan dibagi dengan skor maksimal pada skala 0-100 diperoleh 77 skor rata-rata responden menjadi skor rata-rata kelas. Rata-rata hitung sebesar 82,18 berada pada kategori baik. Skor rata-rata yang diperoleh dari 77 responden secara terperinci untuk setiap indikator dapat digambarkan pada Gambar 4.

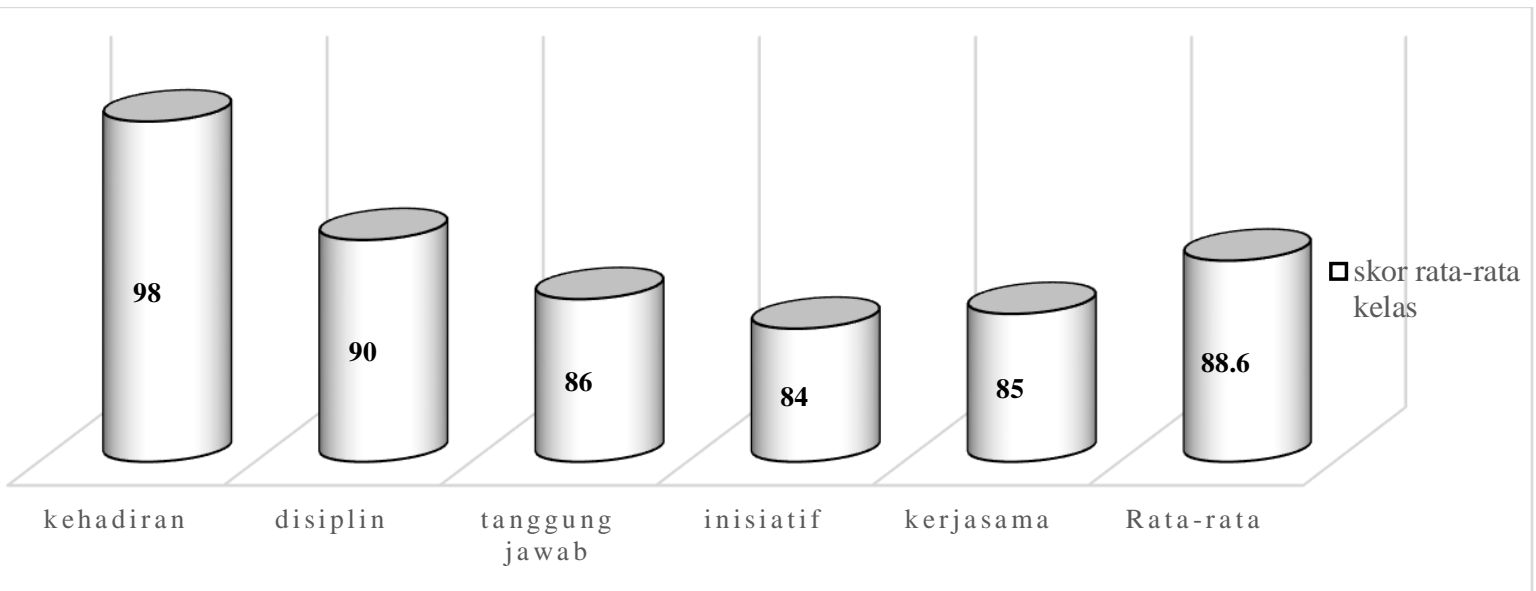

Gambar 4. Grafik skor rata-rata sikap peserta diklat PKG dan PKB

Deskripsi grafik di atas menggambarkan skor rata-rata kelas tertinggi diperoleh pada aspek kehadiran sebesar 98, disiplin sebesar 90, tanggung jawab 86, aspek inisiatif sebesar 84 dan skor rata-rata dari penilaian ke-5 aspek sikap tersebut sebesar 88,6. Dengan membandingkan kriteria dari skor standar, maka secara terinci sebagai berikut:

1) Kehadiran peserta dalam mengikuti diklat sangat baik

2) Disiplin peserta diklat selama mengikuti diklat pada kategori sangat baik

3) Tanggung jawab dalam melaksanakan tugastugas berada pada kategori baik, dalam hal ini masih ada peserta yang mengandalkan orang lain dalam mengerjakan tugas di kelompoknya. Disebabkan karena pemahaman yang masih belum merata.

4) Pada aspek inisiatif peserta diklat teknis substantif PKG dan PKB berada pada kategori baik, sebagian peserta yang memiliki inisiatif dalam menyelesaikan masalah-masalah yang diberikan kepada kelompoknya.

\section{Hasil evaluasi tahap 3-level perilaku (behavior level)}

Pengukuran perilaku atau behavior level dilakukan setelah selesai mengikuti diklat. Evaluasi dilakukan pada aspek-aspek; penerapan kompetensi, peningkatan kualitas kerja, peningkatan kepribadian, peningkatan karir, peningkatan metode pelaksanaan pekerjaan, peningkatan kompetensi, dan peningkatan kuantitas kerja. Selanjutnya pengolahan data pada level 3 ini dilakukan dengan menggunakan t-skor. Rumus yang digunakan adalah sebagai berikut:

skor $-t=50-10\left[\frac{x-\bar{x}}{s}\right]$, dengan:

$x=$ Skor individu setiap item

$\bar{x}=$ Skor Rata-rata setiap item

$s=$ Standar Deviasi setiap item

Untuk menentukan sikap positif (favorable) dan sikap negatif (unfavorable) responden, skor - $\mathrm{t}$ yang sudah diperoleh kemudian dicari nilai rata-rata, dan nilai tengah, kemudian diklasifikasi sebagai berikut:

a. Sikap Positif (favorable) jika titik tengah skor-t > rata-rata kelompok skor-t

b. Sikap negatif (unfavorable) jika titik tengah skor-t $\leq 50$ rata-rata kelompok skor-t 
Hasil Pengolahan data dari 77 responden Kanmenag Kabupaten dan Kota ratarata skor-t responden sebesar 50,00, secara umum dapat disimpulkan bahwa perilaku peserta menunjukkan tidak sesuai dengan diklat atau dengan kriteria menunjukkan 3 indikator perilaku yang sesuai dengan diklat. Lihat instrumen evaluasi level 3 dan hasil pengolahan data level 3.

Setelah dibandingkan antara setiap titik tengah pada setiap item pernyataan terhadap rata-rata kelompoknya, selanjutnya membandingkan data responden level 3 (behavior level)/alumni diklat tahap 2.

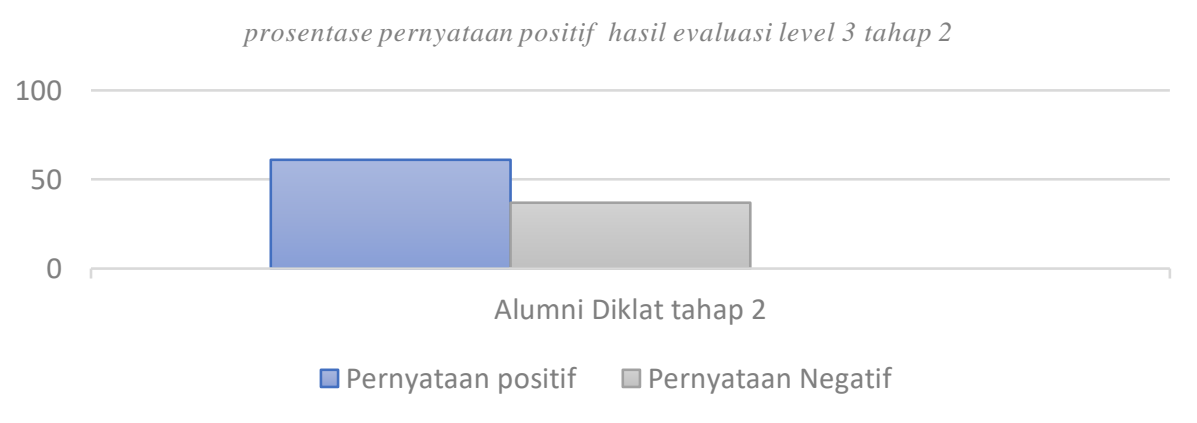

Gambar 5. Grafik persentase pernyataan positif dan negatif level 3

Secara umum hasil evaluasi level 3 tahap 2 dapat dilihat dari grafik nilai rata-rata setelah skor mentah dijadikan skor standar dan dibandingkan dengan nilai tengah setiap item pada instrumen evaluasi kirkpatrick dengan skor - t rata-rata sebesar $61,96 \%$. Hal ini menunjukkan sekitar 47 orang alumni diklat rata-rata kepuasan memberikan pernyataan positif yang artinya hasil diklat memiliki pengaruh yang baik.
Hasil triangulasi data yang diperoleh dari data hasil evaluasi pasca diklat (EPD) Balai Diklat Keagamaan Bandung tahun 2017 dan 2018 pada diklat teknis pendidikan. Data yang dikumpulkan diperoleh dengan analisis data yang sama dengan responden yang bervariasi terdiri dari alumni diklat, atasan langsung dan teman sejawat. Secara umum maka diperoleh prosentase pernyataan positif dan pernyataan negatif dari data laporan EPD tahun 2017 dan tahun 2018 dapat digambarkan dalam Gambar 6.

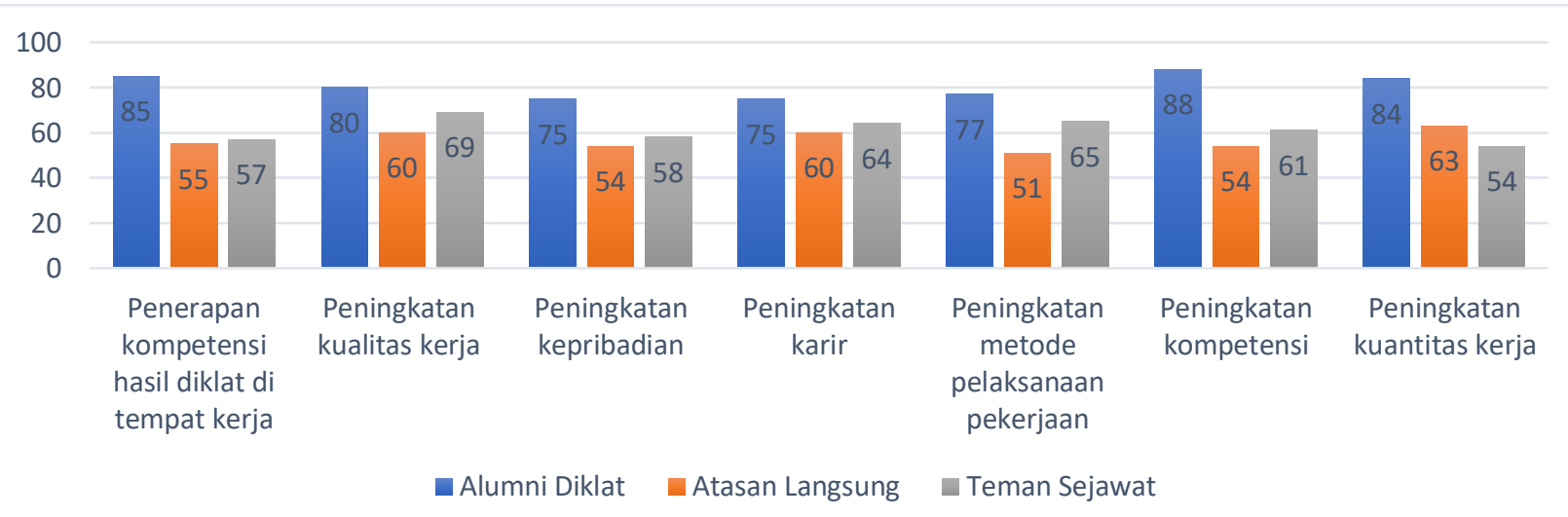

Gambar 6. Persentase pernyataan positif untuk setiap aspek dari alumni diklat atasan langsung dan teman sejawat

Secara umum hasil EPD dan kuesioner menunjukkan rata-rata sebagai berikut: skor rata-rata sebesar 81, alumni diklat menunjukkan bahwa hasil diklat memiliki pengaruh yang baik terhadap peningkatan kompetensinya dan dapat diimplementasikan di tempat kerjanya masing-masing; skor rata-rata sebesar 71, Atasan alumni berpendapat bahwa hasil diklat memiliki pengaruh yang cukup baik terhadap peningkatan kompetensi alumni diklat dan dapat diimplementasikan di tempat kerjanya; skor rata-rata sebesar 62, Rekan sejawat berpendapat bahwa hasil diklat memiliki pengaruh yang kurang baik terhadap 
peningkatan kompetensi rekan sejawatnya dan dapat diimplementasikan di tempat kerjanya.

Dari Grafik di atas diperoleh gambaran bahwa:

1) Penerapan kompetensi hasil diklat di tempat kerja.

Pendapat alumni diklat terhadap pencapaian kompetensi diklat dapat diterapkan sesuai dengan tusinya di instansi masing-masing menunjukkan sikap positif, sedangkan rekan sejawat memberikan pernyataan sikap negatif, namun pernyataan seimbang antara positif dan negatif diberikan oleh atasan.

2) Peningkatan Kompetensi

Indeks kepuasan alumni diklat terhadap peningkatan kompetensi hasil diklat menunjukkan kecenderungan memberikan pernyataan positif, sedangkan rekan sejawat memberikan penilaian negatif adapun atasan memberikan pernyataan positif

3) Peningkatan kinerja secara umum

Dalam hal ini seperti peningkatan kepribadian, peningkatan metode pelaksanaan pekerjaan dan peningkatan peningkatan kuantitas kerja, alumni diklat memberikan kecenderungan pernyataan positif, rekan sejawat dan atasan berpendapat bahwa hasil diklat dapat berdampak peningkatan kinerja secara umum menunjukkan pernyataan sikap cenderung negatif.

4) Peningkatan kinerja secara khusus

Alumni diklat berpendapat bahwa hasil diklat dapat berdampak peningkatan kinerja secara khusus menunjukkan pernyataan positif yaitu pada peningkatan karir tetapi atasan langsung dan teman sejawat menunjukkan pernyataan negatif.

5) Dukungan

Pendapat alumni diklat dan rekan sejawat terhadap dukungan instansi dalam mengimplementasikan hasil diklat menunjukkan pernyataan sikap negatif. Dari hasil pengisian angket serta (wawancara terbuka) ditemukan kendala untuk memenuhi kebutuhan angka kreditnya, seperti guru-guru kesulitan dalam memenuhi angka kredit unsur utama untuk PKB pada unsur diklat. Hal tersebut karena volume penyelenggaraan diklat masih terbatas sehingga kesempatan untuk mengikuti diklat terbatas.

6) Peningkatan Karir

Pendapat alumni diklat, rekan sejawat, dan atasan terhadap hasil diklat terhadap peningkatan karir menunjukkan pernyataan sikap positif. Hal tersebut menunjukkan alumni dapat mengajukan kenaikan pangkatnya meskipun belum semua alumni mendapatkan hasilnya belum merata untuk semuanya karena beberapa kendala seperti untuk pemenuhan angka kreditnya masih kurang.

\section{Hasil evaluasi tahap 1-level hasil (result level)}

Hasil pengolahan data dari 77 responden Kanmenag Kabupaten dan Kota prosentase rata-rata skor-t dapat digambarkan pada grafik berikut.

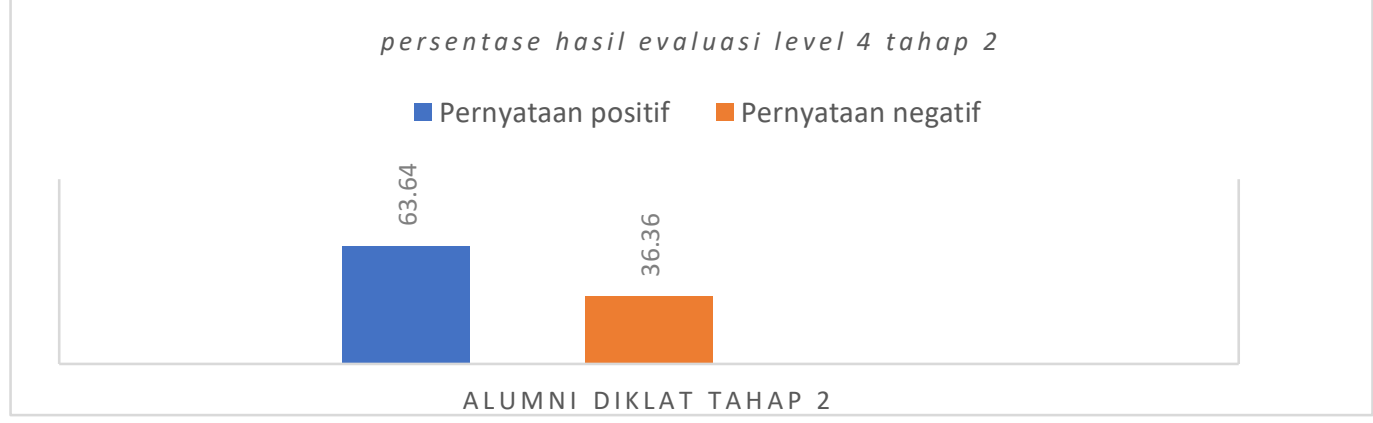

Gambar 7. Persentase Rata-rata Hasil Evaluasi Tahap 4

Berdasarkan grafik prosentase rata-rata skor-t sebesar $63,64 \%$ atau sekitar 49 orang, alumni diklat teknis substantif PKG dan PKB menyatakan positif. Secara terperinci perolehan hasil penskoran dari data mentah dengan menggunakan skor 1 (satu) untuk pernyataan ya atau terdapat hasil dan skor nol (0) untuk pernyataan tidak sesuai dibagi dengan jumlah skor maksimal selanjutnya dikonversi ke dalam skala 0-100 atau dikalikan 100, dapat dilihat pada Tabel 8. 
Tabel 8. Persentase data skor mentah hasil evaluasi level 4

\begin{tabular}{llc}
\hline No. & \multicolumn{1}{c}{ Aspek dan Indikator } & Prosentase \\
\hline 1. & Peningkatan kompetensi setelah diklat & 47,29 \\
& - Menjelaskan Permen PAN-RB nomor 16/2009 tentang jabatan fungsional & \\
& guru dan angka kreditnya & \\
& - Menghitung DUPAK sendiri & 65,62 \\
\hline 2. & Penerapan kompetensi hasil diklat & \\
& - Menghitung DUPAK sendiri & 73,21 \\
& - Menghitung PK Guru & \\
\hline 3. & Peningkatan karir & 55,90 \\
& - Memiliki SK DUPAK baru yang diajukan setelah diklat & \\
\hline 4. & Peningkatan kepribadian & 54,38 \\
& - Menghitung DUPAK sendiri & \\
& - Menyusun karya tulis ilmiah & \\
& - Nilai PK Guru minimal baik & 25,12 \\
\hline 5. & Peningkatan dukungan & \\
& - Tersedianya tim penilai angka kredit & \\
\hline 6. & Peningkatan kinerja & \\
& - Mengajukan DUPAK & \\
\hline & - Menyusun karya tulis ilmiah & \\
\hline
\end{tabular}

Dari tabel dapat digambarkan hasil evaluasi pada tahap 4 - hasil (result level):

1) Rata-rata peningkatan kompetensi peserta diklat PKG dan PKB dengan indikator mampu menjelaskan Permen PAN-RB nomor 16/2009 tentang jabatan fungsional guru dan angka kreditnya serta menghitung DUPAK menunjukkan kategori kurang baik.

2) Pada aspek penerapan kompetensi hasil diklat, alumni diklat PKG dan PKB mampu menghitung DUPAK sendiri, menghitung evaluasi diri PK Guru, sehingga memiliki SK DUPAK baru yang diajukan setelah diklat, rata-rata menunjukkan kategori kurang baik.

3) Peningkatan karir dengan indikator memiliki SK DUPAK baru yang diajukan setelah diklat rata-rata menunjukkan kategori cukup baik.

4) Peningkatan kepribadian dengan indikator mampu menghitung DUPAK sendiri, menyusun karya tulis ilmiah, mengevaluasi diri PK Guru minimal baik rata-rata menunjukkan kategori kurang baik.

5) Peningkatan dukungan dengan indikator tersedianya tim penilai angka kredit, tercukupinya angka kredit pada semua unsur PKG dan PKB guru, rata-rata menunjukkan kategori kurang baik.

6) Peningkatan kinerja dengan indikator mampu mengajukan DUPAK, menyusun karya tulis ilmiah/karya inovatif, nilai PK Guru minimal baik rata-rata menunjukkan kategori kurang baik.

\section{PENUTUP}

\section{Simpulan}

Hasil penelitian Evaluasi Diklat Teknis Substantif Peningkatan Kompetensi Penilaian Kinerja Guru (PKG)/Pengembangan Keprofesionalan Berkelanjutan (PKB) Study Evaluatif dengan Menggunakan Model Kirkpatrick sebagai berikut: Pada level 1 (reaction level), hasil evaluasi peserta terhadap penyelenggara sudah baik, hasil evaluasi peserta terhadap widyaiswara/narasumber untuk semua mata diklat pada 3 (tiga) aspek yaitu pengetahuan, keterampilan dan sikap dengan indeks kepuasan dengan kategori baik rata-rata untuk seluruh mata diklat. Pada level 2 (learning level), pada aspek pengetahuan hasil uji-t data hasil pretest dan posttest memiliki korelasi yang menunjukkan pembelajaran diklat PKG/PKB berhasil meningkatkan pengetahuan peserta diklat. Pada aspek keterampilan kategori 
sangat baik dan aspek sikap rata-rata pada kategori baik. Penilaian kelulusan peserta diklat berdasarkan nilai rata-rata dari ke-tiga aspek pada rata-rata kategori memuaskan.

Evaluasi pada level 3 (behavior level) skor - $\mathrm{t}$ rata-rata sebesar rata-rata alumni diklat memberikan pernyataan positif yang artinya hasil diklat memiliki pengaruh yang baik. Berdasarkan hasil triangulasi data alumni diklat menunjukkan sikap positif, sedangkan rekan sejawat memberikan pernyataan sikap negatif, namun atasan memberikan pernyataan seimbang antara positif dan negatif. Pada level 4 - hasil (result level) hasil evaluasi menunjukkan rata-rata skor-t alumni diklat menyatakan positif, rata-rata menunjukkan kategori kurang baik pada setiap indikator penerapan kompetensi hasil diklat, kemampuan menghitung DUPAK sendiri, menghitung evaluasi diri PK Guru, peningkatan karir, pada aspek peningkatan kepribadian dengan indikator: menyusun karya tulis ilmiah, mengevaluasi diri PK Guru minimal baik, pada aspek dukungan dengan indikator tersedianya tim penilai angka kredit, tercukupinya angka kredit pada semua unsur PKG dan PKB guru, peningkatan kinerja dengan indikator mampu mengajukan DUPAK, menyusun karya tulis ilmiah/karya inovatif, nilai PK Guru minimal baik.

\section{Saran}

Bertolak dari hasil-hasil penelitian dalam meningkatkan evaluasi diklat dengan menggunakan model Kirkpatrick, penulis memberikan saran-saran sebagai berikut: (a) Kepada lembaga Pusdiklat dan Balai Diklat Kementerian Agama, hasil penelitian ini merupakan informasi awal yang dapat memberikan gambaran untuk selanjutnya dapat ditindaklanjuti dengan memperbaiki instrumen evaluasi untuk menerapkan model evaluasi kirkpaktrick untuk setiap level dan menjadi satu kesatuan dalam sistem kediklatan, yang disesuaikan dengan substansi materi diklat; (b) Kepada widyaiswara dapat mengembangkan penelitian ini dan menerapkan model evaluasi kirkpatrick ini pada semua jenis diklat dengan mengembangkan instrumen yang sesuai dengan substansi dan jenis diklatnya terutama untuk evaluasi pada level perilaku (behavior level) dan level hasil (result level). Untuk pelaksanaan evaluasi level perilaku (behavior level) dan level hasil (result level) sebaiknya menjadi satu paket dalam program sebagai sebuah sistem dalam diklat dimasukkan ke dalam struktur kurikulum sebagai tindak lanjut dari diklat dan feeback untuk perbaikan program di masa mendatang, tetapi pelaksanaannya tetap memerlukan tenggang waktu yang cukup untuk memperoleh hasil yang maksimal.

\section{UCAPAN TERIMA KASIH}

Ucapan terima kasih penulis berikan kepada Kepala Balai Litbang Agama Jakarta selaku institusi, Kepala Balai Diklat Keagamaan Bandung, Kemenag Kabupaten Tasikmalaya, Kemenag Kabupaten Subang, Kemenag Kabupaten Purwakarta, alumni diklat teknis substantif PKG/PKB, rekan widyaiswara yang telah memberikan dorongan dan beberapa pihak lain yang telah membantu kelancaran proses penelitian.

\section{DAFTAR PUSTAKA}

Arthur, R. (2018) 'Evaluasi Program Diklat Karya Tulis Ilmiah Untuk Widyaiswara Pusbangtendik Kemdikbud', Jurnal Penelitian dan Evaluasi Pendidikan, 22(1), p. $35 . \quad$ doi: 10.21831/pep.v22i1.16749.

Badu, S. (2013) 'Implementasi Evaluasi Model Kirkpatrick Pada Perkulihan Masalah Nilai Awal dan Syarat Batas', Jurnal Penelitian dan Evaluasi Pendidikan, 48, pp. 102-129.

Dessler, G. and Angelica, D. (2015) Manajemen Sumber Daya Manusia (Human Resource Management). 14th edn. Jakarta: Salemba Empat.

Ikramina, F. and Gustomo, A. (2014) 'Analisysis Of Training Evaluation Process Using Kirkpatrick's Training Evaluation Model at PT> Bank Tabungan Negara (Persero) Tbk.', Journal of Business and Management, Volume 3(kirkpatrick Training Evaluation model), pp. 102-111.

Issac, S. and Michael, W. B. (1995) Handbook in Research and Evaluation: $A$ Collection of Principles, Methods, and 
Strategies Useful in the Planning, Design, and Evaluation of Studies in Education and the Behavioral Sciences. 3rd edn. San Diego, California: EDITS Publishers.

Kirkpatrick, L. D. and James, D. K. (2008) Evaluating Training Programs The Four Levels. San Fransisco: BerretKohler Publishers, Inc.

Noe, R. A. (2010) Employee Training and Development. Fifth edit. Ohio: The Mc Grow-Hill Companies.

Notoatmodjo, S. (2009) Pengembangan Sumber Daya Manusia. Jakarta: PT. Rhineka Cipta.

Peraturan Menteri Pendidikan Nasional nomor 16 (2007) Standar Kualifikasi Akademik dan Kompetensi Guru. Jakarta: Pemerintah Republik Indonesia.

Peraturan Pemerintah (2000) Pendidikan dan Pelatihan Jabatan Pegawai Negeri Sipil. Jakarta: Pemerintah Republik Indonesia.

Ramadhon, S. (2014) 'Penerapan Model Empat Level Kirkpatrick dalam Evaluasi Program Pendidikan dan Pelatihan Aparatur di Pusdiklat Migas', Forum Diklat, 06(1), pp. 43-54. Available at: http://pusdiklatmigas.esdm.go.id/file/d1 _Penerapan Syafril_R.pdf.

Sallis, E. (2010) Manajemen Mutu Terpadu Pendidikan, terj. Edited by A. A. Riyadi and Fahrurrozi. Yogyakarta: IRCSoD.

Silalahi, U. (2012) Metode Penelitian Sosial. Bandung: Reflika Aditama.

Sugiyono (2008) Statistika Untuk Penelitian. Bandung: Alfabeta.

Sugiyono (2011) Metode Penelitian Kombinasi (Mixed Methods). Bandung: Alfabeta.

Ulum, Ö. G. (2015) 'Program Evaluation through Kirkpatrick's Framework', Pacific Business Review International, 8(1), pp. 106-111. Available at: https://www.researchgate.net/publicatio n/295899652_Program_Evaluation_thr ough_Kirkpatrick's_Framework.

Undang-undang (2003) Sistem Pendidikan Nasional. Jakarta: Pemerintah Republik Indonesia.

Undang-undang (2014a) Aparatur Sipil Negara. Jakarta: Pemerintah Republik Indonesia.

Undang-undang (2014b) Pengembangan Kompetensi ASN. Jakarta: Pemerintah Republik Indonesia. 